\title{
Reconstruction of Renewal of Community Development Methods in the World of Islamic Education in the Industrial 4.0 Era
}

\author{
Iswadi ${ }^{1}$, Muntasir $^{2}$, M. Jafar ${ }^{1}$, Halimatussa'diah ${ }^{1}$, Irma Rahmayani $^{1}$, Lindayani ${ }^{1}$ \\ ${ }^{1}$ Lecturer in Islamic Institute of Islam (IAI) Al-Aziziyah Samalanga Bireun Aceh, Indonesia \\ ${ }^{2}$ Lecturer in UNIMAL Lhokseumawe Aceh, Indonesia \\ Email: iswadi83@gmail.com
}

\begin{abstract}
:
Time continues to rotate but the world of Islamic education, which is an inseparable part of the national education system, has the same role as one of the agents of social change, of course, the essence must still be maintained even though innovation changes with time and time shifts. Its existence and existence are also demanded to be able to compensate for the atmosphere of change (modernization) and the Industrial Era 4.0 or millennial era which penetrated into various aspects of life. In the current era (the era now) the world of education must reform with the pressure to create a more comprehensive and flexible education system, so that graduates can function effectively in the life of a democratic global society. Certainly the scientific tradition that developed rapidly in the Industrial Ages 4.0, aroused the awareness of scientists and the general public that mastery of science and technology is a must for the community. The progress and decline of society in the present and future is largely determined by the level of mastery of science, science and technology. This kind of awareness also has the potential to influence the development and efforts to revitalize Islamic scientific traditions.
\end{abstract}

Keywords:

reconstruction; Islamic education; 4.0 era

\section{Introduction}

Discussing the activities of the world of education as if it would never be obsolete in the past eat or escape in time. Educational activities that are always struggling with intellectual horizons and the development of science and technology, demand always dynamic and progressive towards various advances and knowledge that develop in society. Therefore, for thinkers and observers of education, discussing the object of study in the world of education is like looking at an ocean that is difficult to find its edge. It is inseparable from the role of education itself as pengampu human resources to be able to defend their lives. Thus, changes in the mindset, needs and demands of human life automatically also require changes and developments in education systems and activities. In fact, if we look at education that is now promoted it is precisely as provision for the life to come. This means that education should provide experience and knowledge ahead of the various problems that will be faced by humanity. So, when these problems arise, then the people do not feel shocked, nervous, confused or stressed, depressed or even crazy. Therefore, it is natural that at all times fresh ideas in the world of education are always present as an effort to meet and be a solution to the problems of the people.

Rethinking the activities of the world of education means finding new formulas in various educational activities, without any exceptions. Therefore, the unity of Islamic education activities itself as one of the unity of educational activities would need to be considered and obtain fresh thought fertilizers, so that their existence cannot be underestimated. 
The existence of Islamic education should also be able to provide and be a solution to various developmental problems and needs of the people. Thus, finding new formats in the dynamics of Islamic education is a necessity to help humanity. An assumption that is not wise if there is a statement that the activities of Islamic education are only for the afterlife. This statement is in addition to stunting the world of Islamic education, it also contradicts the values of Islamic teachings both originating from the Qur'an or the Sunnah of the Prophet Muhammad. The role of Islamic education is basically trying to provide happiness achievements both in the world and the hereafter.

The history of education in Indonesia has taken place long before Indonesia's independence. Based on historical records that were well recorded, education in the past was mostly held by religious leaders through the boarding schools they care for. In its development now, the implementation of education has been carried out by many countries and communities with any ideological background or understanding. Regardless of who organizes education there is one important thing in the world of education that cannot be done immediately, namely the method of organizing education. The debate over learning methods will never end as long as education continues.

And the important point of the problem in this paper is; First, what is the format of the current education system and whether existing learning methods in the world of education are able to inspire growth and development for students and provide a dialectical discussion space so as to sharpen the reasoning of students so that students are able to compose dreams to encourage the occurrence change both revolutionary and evolutionary? Second, how is the model of reconstructing Islamic education? Third, how does Islamic education see challenges and opportunities in the midst of the Industrial Age 4.0?

On that basis also through the writing of this limited thought, the author hopes to make a positive contribution to the progress of Islamic education in Indonesia in particular and the world in general.

\section{Research Method}

\subsection{Methods for Improving the Quality of Religious Education}

The method used in public religious education will not be much different from the method that can be used by a mother to educate her children. What is obtained by mothers in participating in religious formation can be directly applied and implanted in their respective families. Parents (mothers) as educators in their families are required to be able to give Islamic lessons to their children. Many methods can be used to instill religious knowledge to their children, one of which is to provide a good example or example. However, in applying a method it is necessary to pay attention to the child's psychological development, the content of the material to be conveyed and the objectives to be achieved. In other words, in implementing religious education it is necessary to choose a good, wise method. Broadly speaking, al-Nahlawi, mentions that there are seven main methods of religious education, namely the Hiwar method, the Alqurandan Nabawi method, the Amtsal method, the exemplary method, the habituation method, the ibrah and mauidzah method, the targhib and tarhib methods. these are:

\section{a. The Hiwar Qur'ani and Nabawi Method}

Hiwar is alternating conversations between two parties or more about a topic, and deliberately directed to the purpose of being agreed upon (in this case a teacher). In this 
conversation the material of conversation cannot be limited, so sometimes the conversation comes to a conclusion. Because one party is not satisfied with the other party or any party that has found results. Usually each party in terms of education will be able to pick up students who can determine attitudes for themselves. Hiwar has a positive impact on the speaker and also on the listener, it is caused by several factors, namely as follows:

1. The dialogue takes place dynamically because both parties are directly involved in the conversation, not boring, both parties pay attention to each other, because if they do not pay attention of course they will not be able to follow the mindset of the other party. Each truth or error can be known and responded to immediately, and then the conversation will go on and on. New topics are often found in such talks. The way this method works is the same as free discussion, but here there are teachers who deliberately accompany the conversation towards a certain goal, this is the same as the dialogue conducted by Socrates with his students.

2. The listener is interested in continuing to follow the conversation because he wants to know the conclusion. This is usually followed by being attentive, not bored and looking full of enthusiasm.

3. This method can evoke feelings and create a deep impression in the soul, and help direct someone to find their own conclusions.

4. If the dialogue is done well, fulfilling the morality of Islamic guidance, then the way of dialogue, the attitude of the people involved, it will affect the participants so that it leaves the influence in the form of moral education, attitude in speaking, respecting the opinions of others and so on.

\section{b. Method of the Quranic and Prophetic Stories}

In Islamic education, especially Islamic religious education, the story as a method of education is very important, because the story is always compelling because it invites the reader or listener to follow the event, contemplating its meaning. Furthermore, the meanings will give an impression in the heart of the reader or listener. The Qur'anic story educates the feelings of faith by:

1. Generating a variety of feelings so that it relies on a peak that is the conclusion of the story.

2. Involve the reader or listener in the story so that he is emotionally involved.

\section{c. The Amtsal Method (Parable)}

Sometimes God teaches his people by making parables, for example in Surah AlBaqarah verse 17 It means: "Their parable is like a person who lights a fire, so after the fire illuminates around him Allah removes the light (which illuminates) them, and leaves them in darkness, unable to see". (Al-Baqarah [2]: 17).

\section{Discussion}

Various kinds of criticisms made by observers, practitioners or even thinkers of Islamic education as stated above can be the initial foundation in carrying out renewal of the Islamic education system. Through observation and consideration of various new educational systems or concepts, both those coming from Muslims or non-Muslims can be used as a reference in renewing Islamic education. Especially the ideas related to the renewal of education that support to design the reconstruction of Islamic education. These ideas or thoughts are educational ideas or thoughts that are oriented towards advancing education so that it has relevance to the situation and conditions and the existence of humanity. 
Thus, to formulate the reconstruction of Islamic education there are educational thoughts that will later influence the concept of education. Based on observations and conclusions that the authors get from several educational thinkers, thoughts in initiating the reconstruction of education are formulated or realized with Islamic education models are as follows:

\subsection{Humanist Islamic Education}

One of the ideas that needs to be realized in realizing the reconstruction of Islamic education is respect for human rights as a fitrah. The attitude of oppression or exploitation of human rights in the world of Islamic education must be eliminated. In this case the attitude that exists in initiating the reconstruction of Islamic education is the attitude of respect, uphold and optimize various human nature in order to realize our human beings, which are beneficial for themselves and others.

The humanist concept of education must be an orientation and application in the practice of reconstructing Islamic education. Mutual respect <mutual respect, love for each other and instill educational practices with great love is a necessity in building the humanist Islamic education. In addition, the placement of educational actors between teachers and students as subjects of education must be able to develop all their competencies both in terms of cognitive, affective and psychomotor. In the end, all educational activities or activities must have implications and relevance to the task of human life on earth, namely as the caliph of Allah on earth.

\subsection{Liberating Islamic Education}

The implication in education shows that education as a medium to achieve the degree of piety, gives freedom for each individual to seek knowledge or skills in accordance with their abilities and interests. Because through these educational media, each individual can freely develop various talents or potentials that are able to have beneficial effects both for themselves and for others. These individual rights are free to create individual figures who fear Allah SWT.

Islam respects the freedom of individuals to seek knowledge and skills according to their abilities and desires. With this release it is hoped that he can truly become an expert in the field of science or the skills he is engaged in. The model or form of liberation from the two studies tends to be liberated in terms of scientific interest and skills. In Islam also teaches about other liberation models that are implemented in the field of education such as the liberation of the rules of age, fees and other rules that are all formalistic and cause difficulties for people to seek knowledge.

This liberation means how Islamic educational institutions or institutions in the form of schools, madrasas, pesantren and others should have independence or freedom insofar as they do not violate applicable laws. Thus, independently the Islamic education model will be free from the bondage of the traditionalist Islamic education model. Authoritarian, only emphasizes the cognitive element, as well as from various other weaknesses that are being experienced today. Liberation of Islamic education must also carry an orientation mission that liberates the subject of education from any fetter to build transcendental awareness. In addition, especially if you look at the crisis of the nation and state of Indonesia, then at least Islamic education should be able to free the nation or people from various multidimensional crises that have plagued the motherland. 


\subsection{Democratization of Islamic Education}

The existence of elements of freedom in educational activities is the key or foundation for the realization of Islamic educational democracy. Democratization of Islamic education itself is efforts to create Islamic education that is free from pressures and coercion as well as forms of educational activities that are very bureaucratic, hierarchical, centralistic and elitist.

Thus, to look for alternative formats regarding the democratization of Islamic education it is worth considering various educational thoughts related to this matter. These thoughts either come from Muslims or non-Muslims. The combination of these two ideas is an effort that Islamic education will never go out of style, but it is also able to take something new that is more beneficial and that may not have been touched before.

By studying both of these thoughts (Muslim and non-Muslim), for the reconstruction of education, of course, it must have the content of educational democratization. The current or future Islamic education system must strive to provide, instill the foundations of dialogue, equality, justice, freedom and anti-discrimination. In other words, the democratization of Islamic education can be realized if the creation of several things that are correlated with elements of educational democracy, including: First, academic freedom. Indications of academic freedom in Islamic education if the realization of the freedom of autonomy of Islamic education institutions in various forms to carry out various activities. Second, the creation of diversity or multicultural education. In this aspect in the activities of Islamic education should create an attitude of mutual respect due to differences in a person's background regarding values, culture, social, economic and intellectual abilities. Third, Islamic education for all. Namely all students or students get the same treatment, get the same lessons, so that they get the opportunity or opportunity to achieve scientific competence in accordance with curricular boundaries. Thus, the purpose of education to mature human beings will be achieved so that students have the knowledge to place their skills and skills in accordance with their interests and in accordance with the needs of the labor market.

\subsection{Islamic Education in the Current Industrial Era 4.0}

When we examine the dynamics of historical episodes presented by Muslims throughout the world, we are then entrusted to focus the lens of our analysis in the direction of Islamic education. The reason is that indeed Islamic education has a key role for the continuity of Islam itself. In addition, he greatly determines the character of the Muslim community. In the era of the Industrial Age 4.0 of the world today, as stated by Alvin Toffler that the world is moving into a new world order called the Third wave, a wave of civilization characterized by the advancement of information technology (Information Technology or IT), computerization, biological revolution, war technology and terrorism, etc. that are global in nature. However, the polarization and collaboration of the various characters also resulted in the emergence of "global crises" and "temporary shocks" in the social, economic, political and increasingly rooted bourgeois class sentiments towards the proletariat and the grass root. This phenomenon strengthens and accelerates the occurrence of human tragedies in modern society. Here Alvin invites the modern world community to be aware of the coming of future surprises and rush to preventive efforts through education.

The implications of the Industrial Age 4.0 include the dimensions of information and communication, law, politics, science, culture and religion. Atho Mudzhar explains that in the dimension of science, materialism leads natural science to the idea that matter occupies a central position. The material is used as a starting and ending explanation in a long series of scientific arguments. Inductive science derived from empirical experience occupies a central 
position in the scientific world, while social theological science, which is deductive and originates from the axioms of revelation, is less a reference frame for contemplative thought.

Though the development of science is not sufficiently formulated from the truth (justification) $\neg$ science itself, but it must be seen how the context of its discovery (context of discovery) with values, ethics and morals. So that science can provide the welfare of the lives of people physically and mentally, not providing knowledge that is dry and only physical in nature. According to Muhtarom, science should not only be seen from the practical point of view, or only to obtain worldly material conveniences, but must be open to the context, namely religious values. Science must be a bridge to understanding the nature of God. Such scientific perspectives provide great opportunities for the process of islamization of science in the Industrial Age 4.0 era.

An alarming phenomenon that can be observed in the midst of modern society, including Indonesia, is the emergence of practices in reducing the function of education. Accuracy of education is only relied on efforts to prepare workers (practitioners) with a materialistic orientation, with the pretext of supporting modern industrialization and meeting the needs of large quantities of technology products. In moving towards the Industrial Era 4.0 era, as offered by Zamroni in his idea that the world of education must reform with the pressure of creating a more comprehensive and flexible education system, so that graduates can function effectively in the life of a democratic global society. Based on the ideas offered by Zamroni, for that education must be designed in such a way as to enable students to develop their potential naturally and creatively in an atmosphere full of freedom, togetherness and responsibility. In addition, education must produce graduates who can understand their community with all the factors that can support achieving success. One alternative that can be done is to develop a global education.

The world of Islamic education, too, seems unable to be sterile from the bias of this Industrial Era 4.0 phenomenon. Unfortunately, in facing this phenomenon Islamic education has not been able to place itself in a strategic position. Whereas religious education (Islam) which is loaded with moral and spiritual content can function as one of the therapies for the future shock and humanitarian tragedy of the impact of the Industrial Era 4.0. Islamic education still seems to be confined in a position that tends to be defensive - not to say left behind - and does not have a strong bargaining position, especially towards the offensive in the arena of world civilization. Until now, Islamic education is still treading its identity and role to have a dominant hegemony in the global world.

If we compare it with the modern education system, it must be honestly recognized that the Islamic education system in all elements can be said to be still conservative and conventional. However, it is also recognized that efforts to improve towards a more advanced direction have been carried out, although this has not yet yielded encouraging results. The impact of Muslims until now cannot expect much from the emergence of nuances of new creations and spectacular innovations resulting from Islamic educational institutions, unless one is done, namely the reorientation of various dimensions of Islamic education. On one hand, some Muslims still have a high degree of fanaticism to maintain their traditionalism on the basis of the conservation education paradigm, namely al-muhafadhah 'ala al-qadim alshalih (maintaining good old values). So that raises the attitude of a phobia modernity. On the other hand, because of the insistence of modernity, accepting modernity with innovative principles, namely al-akhdu bi al-jadid al-ashlah (adoption of new values better). Although the adoption of new things that are considered better is still half, due to various obstacles, both 
psychological, political and ideological.

Although frustrated, eventually (in part) Muslims accepted the dualism (colonized) of the education system, namely the modern and traditional systems. So often Muslims are forced to be ambiguous in accepting the offer of modernity from science into the education system. Responding to this dilemma, steps need to be taken to conceptualize the Islamic education system which is more humanistic - functional, has a plus in the context of Islam Indonesian and global. The rapidly evolving scientific tradition of today is arousing the awareness of scientists and the general public that mastery of science and technology is a must for society. The progress and decline of society in the present and future is largely determined by the level of mastery of science, science and technology. This kind of awareness also has the potential to influence the development and efforts to revitalize Islamic scientific traditions.

\section{Conclusion}

Islamic education which is an inseparable part of the national education system has the same role as one of the agents of social change. Therefore, its existence is also demanded to be able to balance the atmosphere of modernization and Industrial Era 4.0 which penetrates various aspects of life.

The assessment of religious education held by schools so far has experienced many shortcomings and even said that it still failed. This failure is caused by the practice of education that only pays attention to the cognitive aspects of the growth of values (religion), and ignores the development of the affective and connotive aspects of evolution, namely the willingness and determination to practice the values of religious teachings. As a result there is a gap between knowledge and practice, between gnosis and practical life in religious values. Or in the practice of religious education turned into religious teaching, so as not to be able to form moral individuals, even though the essence of religious education is moral education, or in the term now called character education.

Thoughts in initiating the reconstruction of education can be realized with several models of Islamic education, namely Islamic education that is humanist, Islamic education that liberates and democratizes education. In the Industrial Age 4.0 era, the world of education must carry out reforms with pressure to create a more comprehensive and flexible education system, so that graduates can function effectively in the life of a democratic global society.

\section{References}

Ahmad Dien Marimba. 1989. Pengantar Filsafat Pendidikan, Bandung: Al-Ma'arif. Ahmad Tafsir. 1992. Ilmu Pendidikan Dalam Perspektif Islam, Bandung, Rosdakarya.

Adurrahman An-Nahlawi. 1989. Prinsip-Prinsip Dan Metode Pendidikan Islam Dalam Keluarga, Sekolah dan Masyarakat, Bandung, Diponegoro.

A. Malik Fajar. 1998. Visi Pembaharuan Pendidikan Islam, Jakarta: LP3NI.

Abd. Rahman Assegaf dalam Imam Machali dan Mustafa (eds). 2004. Pendidikan Islam dan Tantangan Era Industri 4.0; Buah pikiran seputar Filsafat, Politik, Ekonomi, Sosial dan Budaya, Yogyakarta: Presma. Fak. Tarbiyah UIN Sunan Kalijaga.

Achmadi. 2005. Ideologi Pendidikan Islam; Paradigma Humanisme Geosentris Yogyakarta: Pustaka Pelajar.

Alfin Tofler. 1992. The Third Wave, (Gelombang Ketiga), terj. Dra. Sri Koesdayantinah, Jakarta: PT.Prantija Simpati. 
Atho Mudzhar. 1998. Pendekatan Studi Islam dalam teori dan Praktek, Yogyakarta: Pustaka Pelajar. Hadari Nawawi. 1993. Pendidikan Dalam Islam, Algensindo, Surabaya: Al-Ma'arif.

Hasbullah, Muntasir, Saiful Bahri, Riska Zahara, Zulfia, Messages Communication in the Al-Qur'an (Study of Messages in the Al-Qur'an for Believers), Budapest International Research and Critics Institute-Journal (BIRCI-Journal): Volume 2.No.4, November 2019. (http://www.bircu-journal.com/index.php/birci/article/view/569)

Helmi, Saiful Bahri, Riyandi, Nurazizah, Nurmasyitah, Implementation Place of 'Uqubat Canings in Fiqh Perspective (Analysis of Aceh Governor Regulation Number 5 of 2018), Budapest International Research and Critics Institute-Journal (BIRCI-Journal): Vol. 2.No.4, November 2019.

(http://bircu-journal.com/index.php/birci/article/view/553/pdf)

Imam Tholkhah dan Ahmad Barizi. 2004. Membuka Jendela Pendidikan; Mengurai Akar Tradisi dan Integrasi Keilmuan Pendidikan Islam, Jakarta: PT. Raja Grafindo Persada,

Khozin. 2001. Jejak-jejak Pendidikan Islam di Indonesia, Malang: UMM Press.

M. Imam Zamroni. 2000. Paradigma Pendidikan Masa Depan, Yogyakarta: BIGRAF Publishing,.

M. Imam Zamroni. 2004. Pendidikan dan Pemberdayaan Masyarakat Kecil, Yogyakarta: Presma UIN Sunan Kalijaga.

M. Toyyibi. 1999. Filsafat ilmu dan perkembangannya, Surakarta: Muhammadiyah University Press.

Muhaimin. 2005Pengembangan Kurikulum Pendidikan Islam di Sekolah, Madrasah dan Perguruan Tinggi, Jakarta: PT. Raja Grafindo Persada.

Muhtarom H.M., Reproduksi Ulama di Era Era Industri 4.0: Resistensi Tradisional Islam, (Yogyakarta: Pustaka Pelajar, 2005, 79)

Muntasir, Saiful Bahri, Yusfriadi, Muttaqien, Ahmad Nidal, Fadlon, Human Communication with God through Asmaul Husna (99 Names of Allab) (Study of Asmaul Husna's Understanding in Islamic Theology), Britain International of Humanities and Social Sciences (BioHS) $\begin{array}{llllll}\text { Journal: } & \text { Volume. } & 1 & \text { No. } & 2 & \text { October }\end{array}$ http://biarjournal.com/index.php/biohs/article/view/45

Munzir Hitami, Mengonsep Kembali Pendidikan Islam, Riau: Infinite Press, 2004

Muzaiyyin Arifin, Kapita Selekta Pendidikan Islam, Jakarta: PT. Bumi Aksara, 2003

Saiful Bahri, Syarkawi Syarkawi, Mursal Mursal, Fizazuawi Fizazuawi, Maimun Maimun, Trust Giving Transactions on Mu'amalah Al-Wadi'ah, Budapest International Research and Critics Institute-Journal (BIRCI-Journal) Volume 2 No. 1, 2019, http://bircujournal.com/index.php/birci/article/view/51-57

Saiful Bahri, Hadiths About Communication Ethics (Study of Hadiths about Responsibility and Maintaining Information Accuracy), Budapest International Research and Critics InstituteJournal (BIRCI-Journal) Volume 1 No. 4, December 2018, http://www.bircujournal.com/index.php/birci/article/view/118.

Soleh Subagja. 2010. Gagasan Rekontruksi Pendidikan, Malang: Madani.

Zakiah Daradjat,. 2002. Pendidikan Islam dalam Keluarga dan Sekolah, Bandung: Remaja Rosda Karya. 